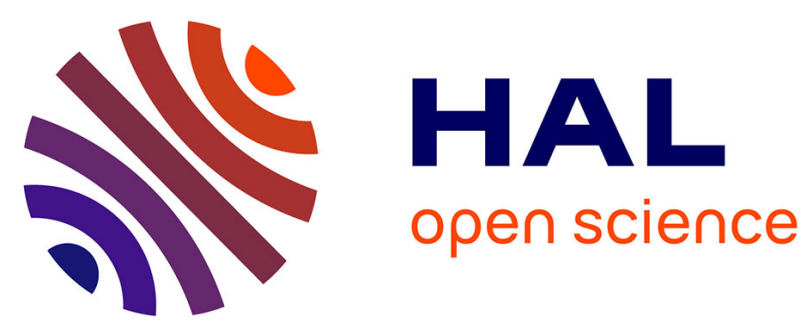

\title{
Contribution of Saharan dust on radionuclides aerosol activity levels in Europe? The 21-22 february 2004 case study
}

Laurent Menut, Olivier Masson, Bertrand Bessagnet

\section{> To cite this version:}

Laurent Menut, Olivier Masson, Bertrand Bessagnet. Contribution of Saharan dust on radionuclides aerosol activity levels in Europe? The 21-22 february 2004 case study. Journal of Geophysical Research: Atmospheres, 2009, 114 (art D16202), pp.NC. 10.1029/2009JD011767 . ineris-00963183

\section{HAL Id: ineris-00963183}

https://hal-ineris.archives-ouvertes.fr/ineris-00963183

Submitted on 5 Aug 2021

HAL is a multi-disciplinary open access archive for the deposit and dissemination of scientific research documents, whether they are published or not. The documents may come from teaching and research institutions in France or abroad, or from public or private research centers.
L'archive ouverte pluridisciplinaire HAL, est destinée au dépôt et à la diffusion de documents scientifiques de niveau recherche, publiés ou non, émanant des établissements d'enseignement et de recherche français ou étrangers, des laboratoires publics ou privés.

$$
\text { Copyright }
$$




\title{
Contribution of Saharan dust on radionuclide aerosol activity levels in Europe? The 21-22 February 2004 case study
}

\author{
Laurent Menut, ${ }^{1}$ Olivier Masson, ${ }^{2}$ and Bertrand Bessagnet ${ }^{3}$ \\ Received 19 January 2009; revised 28 April 2009; accepted 3 June 2009; published 20 August 2009.
}

[1] In February 2004, a spectacular dust event was observed in the south of France. Associated with huge particulate matter deposition, unusual ${ }^{137} \mathrm{Cs}$ concentrations were found in samples. Using the transport model CHIMERE-DUST, we first show that these dust aerosols came from North Africa. More precisely, the question is whether this sudden increase of measured ${ }^{137} \mathrm{Cs}$ concentrations was due to a huge amount of dust over a large region (with an usual radionuclide content) or due to an import of more concentrated air masses over a limited area. This question is connected to the open debate about the contribution of ${ }^{137} \mathrm{Cs}$ concentrations in Europe from "Gerboise" sites, where former French nuclear tests in the 1960s were performed. With the model in scenario mode, this study attempts to track down ${ }^{137} \mathrm{Cs}$ concentrations recorded in the south of France. To quantify the origin and percentage of dust originating from North Africa to the south of France, three simulations are performed: (1) with the complete dust emissions inventory of Africa, (2) with only emissions in the eastern Maghreb, and (3) only considering the Gerboise sites. It is showed that the majority $(80 \%)$ of the dust was coming from eastern Maghreb, but only $0.7 \%$ of the African emissions were from Gerboise, leading to $1-5 \%$ of the concentrations recorded in the south of France for the day of the peak.

Citation: Menut, L., O. Masson, and B. Bessagnet (2009), Contribution of Saharan dust on radionuclide aerosol activity levels in Europe? The 21-22 February 2004 case study, J. Geophys. Res., 114, D16202, doi:10.1029/2009JD011767.

\section{Transport and Deposition of Radionuclides in Particulate Matter}

[2] The deposition of particles containing anthropogenic radionuclides is studied because they are commonly used as tracers to discriminate the origin of long-ranged transport particles [Igarashi et al., 2001, 2005; Fukuyama and Fujiwara, 2008]. Even if concentrations are very low (without harmful effects), soils samples sometimes contains radionuclide concentrations slightly up to the usual background values. The origin of this amount is recognized to be due to former global weapons tests [Aoyama et al., 2006].

[3] The identification of sources may be complex because the radionuclides bound to aerosols may be deposited and after resuspended in the atmosphere, and so on, leading to a dilution effect and homogenization both in time and space. For example, the contaminated soils of Chernobyl caused severe health damages just around the site, but also longrange transport and soil contaminations far from the site [Pollanen et al., 1997]. But after more than 20 years, it

\footnotetext{
${ }^{1}$ Laboratoire de Météorologie Dynamique, Institut Pierre-Simon Laplace, Ecole Polytechnique, Palaiseau, France.

${ }^{2}$ Service d'Etudes et de Surveillance de la Radioactivité dans l'Environnement, Direction de l'Environnement et de l'Intervention, Institut de Radioprotection et de Sûreté Nucléaire, Saint Paul lez Durance, France.

${ }^{3}$ Institut National de l'Environnement Industriel et des Risques, Verneuil en Halatte, France.
}

Copyright 2009 by the American Geophysical Union. 0148-0227/09/2009JD011767 becomes difficult to know if an air mass, locally emitted, contains materials from Chernobyl or not [Wagenpfeil et al., 1999; De Cort, 1998]. Only a fine isotopic study is thus able to discriminate the real origin of such samples. Papastefanou et al. [2001] suggested that Chernobyl particles may be reemitted from remote sites, including the Saharan region. But, a Chernobyl pollution of Sahara is not clear and Brandt et al. [2002] showed that the plume did not reach the north of Africa during the week of the accident.

[4] From measurements in sand in North Africa (mostly in Algeria), Baggoura et al. [1998] showed the most important activity levels are found near the Mediterranean sea. The Saharan part of the country exhibits the lowest measured levels. More recently, Danesi et al. [2008] presented local measurements of radionuclides in the former French nuclear weapon test sites in Algeria, where the "Gerboise" experiments took place. For black fragments of fused sand, and for a very specific small surface, samples had the concentrations of ${ }^{137} \mathrm{Cs}=29 \cdot 10^{3} \mathrm{~Bq} \mathrm{~kg}^{-1}$. Danesi et al. [2008] more generally concluded that local activity is very small and not harmful for inhabitants in this region. However, they also suggest to promote a new measurement campaign to explore more sites. Latitudinal band from $20^{\circ} \mathrm{N}$ to $30^{\circ} \mathrm{N}$ in which Sahara is present also receives part of the so called global fallout from worldwide nuclear tests contributing to a background anthropogenic activity level in soil [United Nations Scientific Committee on the Effects of Atomic Radiation, 1982]. Nevertheless, measurements in sand do not reflect the ${ }^{137} \mathrm{Cs}$ concentrations in aerosolized 
matter because ${ }^{137} \mathrm{Cs}$ is preferentially absorbed onto fine silt particles [Campbell et al., 2008].

[5] On 22 February 2004, a huge dust event occurred in the south of Europe. Huge quantities of dust were deposited: values were so high that instruments became unusable. The event was identified as coming from the Sahara. In this paper, we will try to add some inputs to answer the following question: Is it possible that particles with high activity levels, issued from former nuclear tests, significantly contribute to ${ }^{137} \mathrm{Cs}$ concentrations in dust analyzed in the south of France? To answer this question, we use the CHIMERE-DUST model [Menut et al., 2007] in a scenario mode (with three different dust emissions inventories) and measurements of surface particulate matter (PM) and ${ }^{137} \mathrm{Cs}$ concentrations. Section 2 is devoted to present the studied case, the 21-23 February 2004 period and all related measurements. Section 3 presents the dust production and transport model used for this study, CHIMERE-DUST. Finally, section 4 presents the results of this study and concludes on the relative amount of dust coming from a potentially contaminated site.

\section{Dust Episode on 22 February 2004}

[6] The Saharan dust events have been recognized to have a non negligible impact on the Particulate Matter $\left(\mathrm{PM}_{10}\right)$ surface concentrations recorded in Europe [e.g., Putaud et al., 2004; Lyamani et al., 2005; Escudero et al., 2007; Vanderstraeten et al., 2008]. Their contribution is added to the local production, mostly because of local resuspension. This local production is viewed as a "background" contribution, regular in time and mainly depending on the season. Moreover, the long-range transport of dust coming from the Saharan region is more sporadic and intense: but it was shown that even far from the sources, it may contribute significantly to the local PM budget [Colette et al., 2008].

[7] In the same time, and for the period of February 2004, measurements of ${ }^{137} \mathrm{Cs}$ were performed by a French institute (IRSN) in deposited dust samples and showed unusual values. Usually, background trace levels are more or less constant during the year. With a continuous analysis of particles in the Canary Island Tenerife, Karlsson et al. [2008] showed that it is possible to correlate some saharan dust outbreaks to ${ }^{137} \mathrm{Cs}$ concentration levels. For the most important recorded values, the back trajectories crossed over Morocco, west Sahara, Algeria, Mali and Mauritania. In order to check the possible origin of these radionuclides, Masson and Cautenet [2005] estimated and compared ${ }^{137} \mathrm{Cs}$ and ${ }^{239+240} \mathrm{Pu}$ concentrations. If the ratio of ${ }^{137} \mathrm{Cs} /{ }^{239+240} \mathrm{Pu}$ is greater than 40 it is admitted that an additional source than global fallout is involved [Pollanen et al., 1997; Brandt et al., 2002; Kulan, 2006]. If the ratio is in the range $30-40$, the origin of the episode may be related to global nuclear tests. Issued from deposited samples, other measurements showed that the recorded levels were ${ }^{137} \mathrm{Cs}=$ $38 \mathrm{~Bq} \mathrm{~kg}^{-1}$ dry, ${ }^{239+240} \mathrm{Pu}=1 \mathrm{~Bq} \mathrm{~kg}{ }^{-1}$ dry and ${ }^{241} \mathrm{Am}=$ $0.46 \mathrm{~Bq} \mathrm{~kg}^{-1}$ dry. With a ratio of ${ }^{137} \mathrm{Cs} / 239+240 \mathrm{Pu}=37.14$, this event is certainly not due to local resuspension matter or long-ranged Chernobyl recirculation. In terms of deposition, this single event represents a deposition equivalent to that recorded on average over nine months.
[8] Figure 1 presents measurements of atmospheric concentrations of ${ }^{137} \mathrm{Cs}$ recorded for several sites in France and for the first four months of 2004. All measurements are related to cities in the whole France, and the southern location is La Seyne sur mer. This is the place of the highest peak recorded, the only site where the 10 days averaged measurements is greater than $1 \mu \mathrm{Bq} / \mathrm{m}^{3}$. The peak time corresponds to the studied period of February 2004.

[9] Table 1 shows daily radionuclide measurements done in southern France and for the studied episode of February 2004: Ajaccio, Cadarache, Nice and Montfaucon (see Figure 2 for locations). These data are issued from the OPERA French network as described by Bouisset et al. [2004]. The network includes more than 1500 measurements of activity levels in air and soils. Several species are monitored and uncertainty values are available for some of them, depending on the detection level of each instrument and the time variability of the measured event. In the case of this study, no uncertainties values were available with the measurements used.

[10] Values are in $\mu \mathrm{Bq} \mathrm{m}^{-3}$ and showed the increase of ${ }^{7} \mathrm{Be},{ }^{210} \mathrm{~Pb}$ (natural radionuclides) and ${ }^{137} \mathrm{Cs}$ (anthropogenic radionuclide) levels in air when the dust plume flew over the south of France. The radionuclides concentrations are clearly higher, but this is not a proof of more contaminated particles as values are linearly linked to the dust concentrations themselves: it is possible to have more ${ }^{137} \mathrm{Cs}$ only because there is more dust, not because dust are more contaminated.

[11] Integrated data are also available with OPERA: for a period ranging a few days around this episode (2025 February 2004), values were recorded at La Seyne sur Mer (same model grid cell than Saint Louis in Figure 2) with ${ }^{137} \mathrm{Cs}=1.96 \mu \mathrm{Bq} \mathrm{m}{ }^{-3}$, corresponding to 4 times more than the annual mean value. The assessment of the activity level at the time of the peak of PM10 recorded locally (only during the dust passage (21-22 February) yields to $5.4 \mu \mathrm{Bq} \mathrm{m}^{-3}$. In mass, the activity level is measured at 20 to $38 \mathrm{~Bq} \mathrm{~kg}^{-1}$ corresponding to 3 to 6 times the annual average for this site. This latter in mass shows that this saharan dust sampled in France are more marked than usual local dust.

\section{Model Setup}

\subsection{General Model Design}

[12] Two different models are used in this study: the first one, CHIMERE [Bessagnet et al., 2004], is used to compute surface concentrations of particulate matter (PM) inside Europe. These PM are only originated from anthropogenic and biogenic emissions calculated in western Europe. They include dust issued from emissions and resuspension as described by Vautard et al. [2006]. The second model is CHIMERE-DUST: this is a specific version of CHIMERE, with a larger domain (see Figure 2) and dealing only with Saharan dust emissions and transport.

[13] Apart these differences, both models characteristics are the same: they are off-line models and the meteorology is calculated with the MM5 model forced by the NCEP global meteorological fields. The horizontal analysis data of NCEP [Kalnay et al., 1996] are provided on a regular $1.125^{\circ} \times 1.125^{\circ}$. These fields are used as boundary conditions and nudging for the MM5 model [Dudhia, 1993]. 


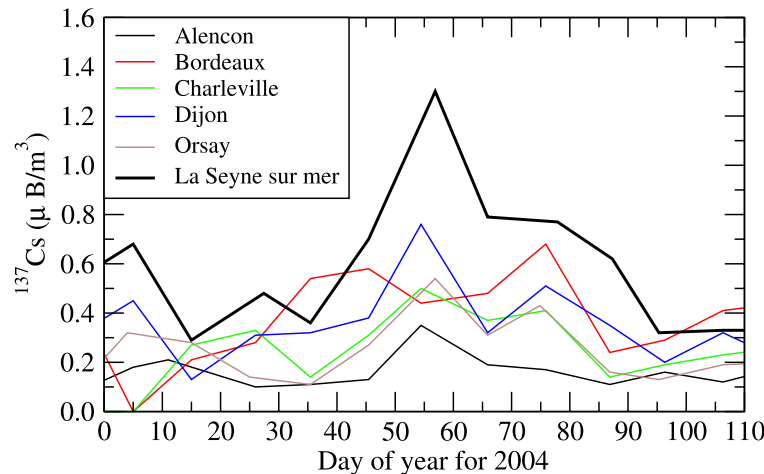

Figure 1. Time series of surface ${ }^{137} \mathrm{Cs}$ concentrations (in $\mu \mathrm{Bq} \mathrm{m}^{-3}$ ) measurements done in France by the OPERA network.

[14] Turbulent parameters as $u_{*}$, the friction velocity and $\bar{h}$ the boundary layer depth are estimated from the mean meteorological parameters. The horizontal transport is performed using the Van Leer scheme [Van Leer, 1979] and the vertical mixing is estimated from the calculation of the bulk Richardson number as extensively described by Menut [2003]. Vertical transport includes both mixing and advection processes. Mixing is treated with an eddy diffusion parameterization [Troen and Mahrt, 1986] while advection is resolved using a first-order Upwind scheme. The dust simulations are performed with a time step of $10 \mathrm{~min}$ and the results are stored every hour for analysis.

[15] More precisely for CHIMERE-DUST, the dust emission scheme used in the model is the Marticorena and Bergametti [1995] scheme. It computes horizontal saltation fluxes from wind velocities and surface features for the "EMISSIONS" area (Figure 2) using a two-parameter Weibull distribution for the wind speed [Menut, 2008]. The dust vertical fluxes are computed by using the Alfaro and Gomes [2001] parameterization, numerically optimized following Menut et al. [2005]. The vertical fluxes are calculated corresponding to three dust size modes, then redistributed into the model size bins using a mass partition scheme. The wet deposition scheme is that described by Loosmore and Cederwall [2004]. The dry deposition velocity is parameterized following Venkatram and Pleim [1999].

[16] The horizontal domain has an horizontal resolution of $1^{\circ} \times 1^{\circ}$ and is displayed as the "CHIMERE-DUST domain" frame in Figure 2 and with $-100^{\circ}<$ longitude $<$ $+80^{\circ}$ and $-5^{\circ}<$ latitude $<+65^{\circ}$. Vertically, 30 levels are defined from the surface to $200 \mathrm{hPa}$. The vertical resolution is about $50 \mathrm{~m}$ in the boundary layer until $2 \mathrm{~km}$ in the upper troposphere.

\subsection{Modeling the Case Study}

[17] For CHIMERE, the model setup is the one used for the PREVAIR French air quality daily forecast [Honoré et al., 2008].

[18] For CHIMERE-DUST, the simulation was performed from 1 February to 5 March 2004, in order to completely cover the whole period (with a correct spin-up). Three different simulations are performed:

[19] 1. The "all" configuration corresponds to the original version of the CHIMERE-DUST model with the complete surface emissions inventory, as used by Mепиt et al. [2007].

[20] 2. The "eastern Maghreb" configuration corresponds to a specific version of the emissions: only the area encompassing the eastern Maghreb (see map in Figure 2) is considered for dust emissions. All other dust emissions fluxes are set to zero.

[21] 3. The "Gerboise" configuration is the same as the previous one, but only emissions over the Gerboise small areas $\left(1^{\circ} \times 1^{\circ}\right)$ are considered. This latter configuration enables us to quantify the relative amount of dust due to the Gerboise site only.

\section{Model Results}

\subsection{Time Series of Particulate Matter Surface Concentrations}

[22] Figure 3 presents time series of surface concentrations for two sites in the south of France: Avignon and Saint-Louis. The symbols represent the measurements and the solid black line the corresponding PM10 values modeled with CHIMERE in the same configuration as in the work by Honoré et al. [2008] without dust for boundary conditions. This version allows to calculate the PM10 related to anthropogenic activities only. The colored curves represent the CHIMERE-DUST model: in this case only dust emitted in northern Africa are considered. Compared to measurements, the results clearly show that missing PM concentrations are due to Saharan dust, confirming the Saharan origin of this episode.

[23] The modeled dust peak value is close to the measured one. The time of the modeled dust is centered on the measured one, with a larger extension meaning that the model estimates a peak slightly too early and the plume stays more longer than what was observed.

[24] The "eastern Maghreb" contribution is the major part of the dust modeled in the south of France. It is noteworthy that the sole "Gerboise" site contribution is rather low. With maxima values of 2 to $5 \mu \mathrm{g} \mathrm{m}^{-3}$, the net contribution of "Gerboise" remains low in mass compared

Table 1. Daily Averaged Values of ${ }^{7} \mathrm{Be},{ }^{210} \mathrm{~Pb}$, and ${ }^{137} \mathrm{Cs}$ at Ground Level for 19-22 February 2004 ${ }^{\mathrm{a}}$

\begin{tabular}{|c|c|c|c|}
\hline Date & ${ }^{7} \mathrm{Be}$ & ${ }^{210} \mathrm{~Pb}$ & ${ }^{137} \mathrm{Cs}$ \\
\hline \multicolumn{4}{|c|}{ Ajaccio } \\
\hline $19 \mathrm{Feb}$ & $3000 \pm 1220$ & $740 \pm 90$ & $<0.7 \pm$ \\
\hline $21 \mathrm{Feb}$ & $1430 \pm 770$ & $450 \pm 60$ & $2.2 \pm 0.5$ \\
\hline $22 \mathrm{Feb}$ & $4400 \pm 2200$ & $860 \pm 100$ & $7.4 \pm 1.3$ \\
\hline \multicolumn{4}{|c|}{ Cadarache } \\
\hline $19 \mathrm{Feb}$ & $3050 \pm 360$ & $805 \pm 70$ & $<1.2$ \\
\hline $20 \mathrm{Feb}$ & $2230 \pm 260$ & $460 \pm 40$ & $<0.7$ \\
\hline $21 \mathrm{Feb}$ & $1690 \pm 210$ & $350 \pm 35$ & $2.2 \pm 0.6$ \\
\hline $22 \mathrm{Feb}$ & $1550 \pm 220$ & $440 \pm 40$ & $2.2 \pm 0.6$ \\
\hline \multicolumn{4}{|c|}{ Nice } \\
\hline $19 \mathrm{Feb}$ & $4200 \pm 825$ & $1150 \pm 100$ & $<1.3$ \\
\hline $20 \mathrm{Feb}$ & $3100 \pm 550$ & $490 \pm 50$ & $<1.3$ \\
\hline $21 \mathrm{Feb}$ & $1300 \pm 330$ & $290 \pm 35$ & $1.2 \pm 0.85$ \\
\hline $22 \mathrm{Feb}$ & $570 \pm 250$ & $165 \pm 20$ & $1.6 \pm 0.5$ \\
\hline \multicolumn{4}{|c|}{ Montfaucon } \\
\hline $19 \mathrm{Feb}$ & $1900 \pm 450$ & $525 \pm 50$ & $<0.9$ \\
\hline $20 \mathrm{Feb}$ & $1800 \pm 425$ & $410 \pm 40$ & $<1.1$ \\
\hline $21 \mathrm{Feb}$ & $1590 \pm 415$ & $560 \pm 50$ & $1.5 \pm 0.6$ \\
\hline $22 \mathrm{Feb}$ & $2550 \pm 550$ & $640 \pm 60$ & $3.5 \pm 0.9$ \\
\hline
\end{tabular}

${ }^{\mathrm{a}}$ Unit is $\mu \mathrm{Bq} \mathrm{m}{ }^{-3}$. 

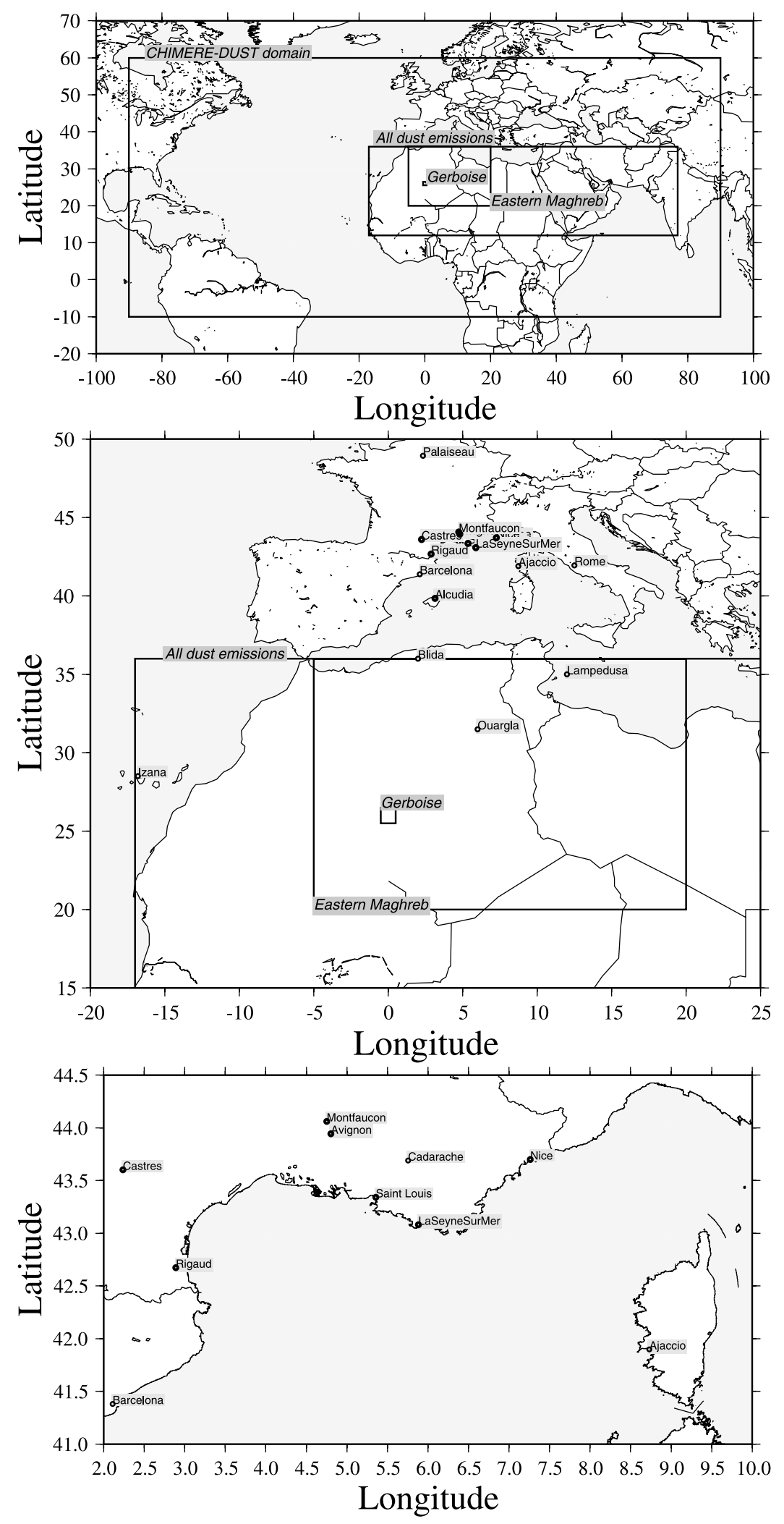

Figure 2. (top) CHIMERE-DUST model domain, including the specific emissions domain "EMISSIONS." (middle) A zoom on the domain and the modeled and measurements sites, including the area called "Gerboise bleue." (bottom) A zoom on the stations where ${ }^{137} \mathrm{Cs}$ was analyzed and/or PM stations are located. 

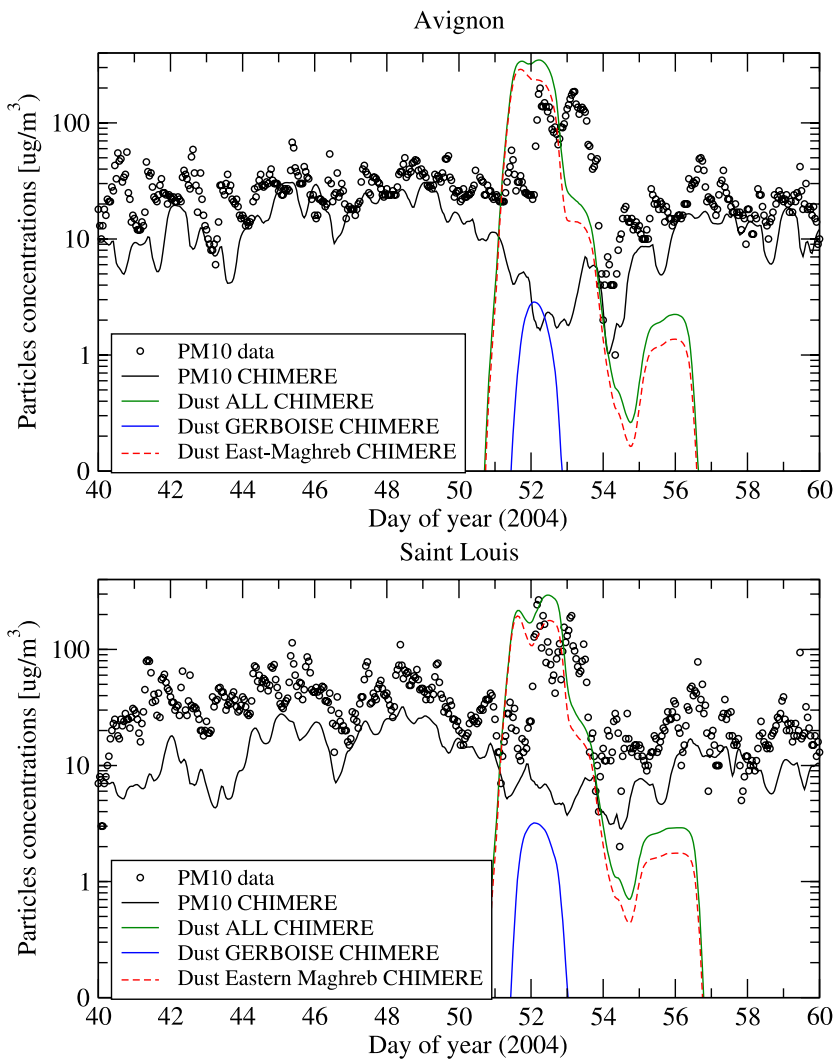

Figure 3. Surface time series of surface PM10, measured and modeled with CHIMERE, and surface dust concentrations modeled with CHIMERE-DUST for the three configurations "all," "eastern Maghreb," and "Gerboise." Day 53 is 22 February 2004.

to the huge PM surface concentrations measured and modeled. Moreover, the peak time of the "Gerboise" dust shows a good timing with the ${ }^{137} \mathrm{Cs}$ peaks recorded in the south of France.

\subsection{African Dust Surface Concentrations}

[25] To highlight the relative contribution of "eastern Maghreb" and "Gerboise" compared to the "all" simulation, Figure 4 presents surface concentrations times series. Values are displayed for remote sites in the northern Africa (Ouargla), southern parts of France (Cadarache, Ajaccio) and Italy (Lampedusa, Rome).

[26] For the "all" simulation, surface concentrations present peaks at several time. From the Julian day 51 (20 February) to 53 (22 February), the model estimates very high surface dust concentrations with a magnitude in agreement with surface measurements. The most important values are estimated for the two islands: Ajaccio in Corsica and Lampedusa. In this case, the high values may be linked to the specific dynamic of the marine boundary layer, having a lesser extent than over land and thus concentrating dust during the transport above the Mediterranean sea.

[27] The same trend is observed for the "eastern Maghreb" model configuration. The absolute values are slightly lower but the time phase is the same and, for each individual site, the peak time is close to the "all" simulation.
[28] For the "Gerboise" simulation, values are lower, with a maximum of $20 \mu \mathrm{g} \mathrm{m}^{-3}$ in Ouargla (Algeria), the relative contribution of Gerboise in concentration is low. For the southern France and Italy sites, the maxima are never higher than $5 \mu \mathrm{g} \mathrm{m}^{-3}$ and peak times are the day before the studied day (21 February 2004).

[29] Figure 5 shows surface concentrations as maps and for 22 February 2004 (0000 UTC), for the "all," "eastern Maghreb" and "Gerboise" simulations. The main part of the plume is clearly coming from the Sahara and is transported toward the south of France and Italy. The "eastern Maghreb" simulation shows the same pattern than the "all" simulation, except in the south. For the northern part of the plume, this is clear that the most of aerosols observed in Europe originated from this region. The "Gerboise" simulation shows a less diffuse plume, with a clear shape from the Gerboise site to the southern France surface stations where high ${ }^{137} \mathrm{Cs}$ concentrations were analyzed.

\subsection{Relative Contribution: Cumulated Results}

[30] The relative contributions of "eastern Maghreb" and "Gerboise" are presented. First, integrated results are presented in Figure 6 as ratios of Int(Gerboise)/Int(all) and Int(eastern Maghreb)/Int(all). Time series show the relative
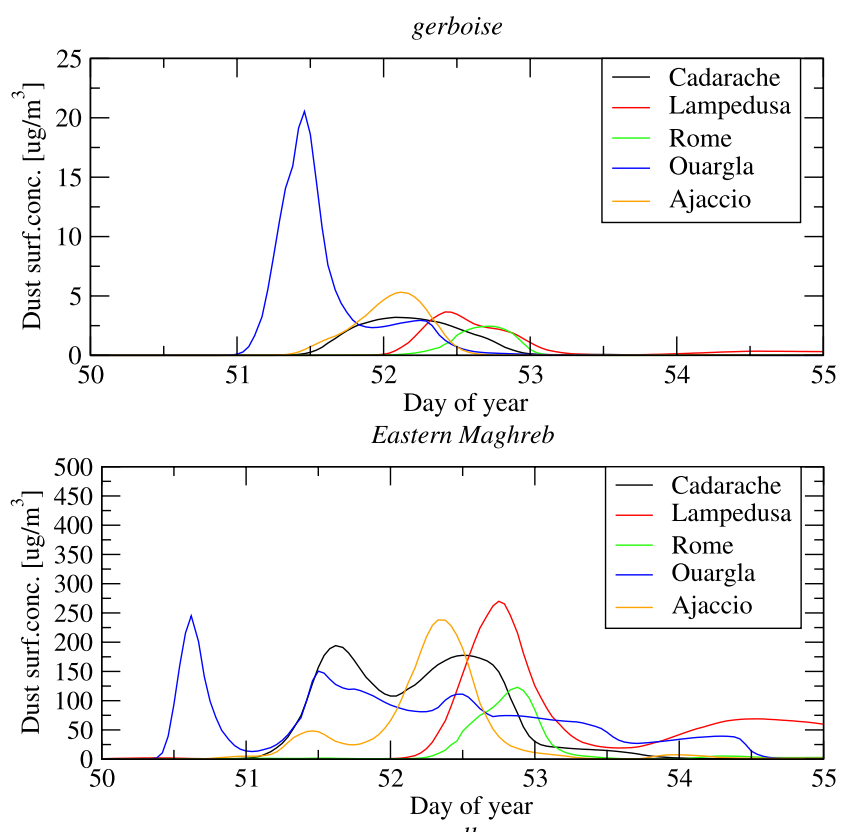

all

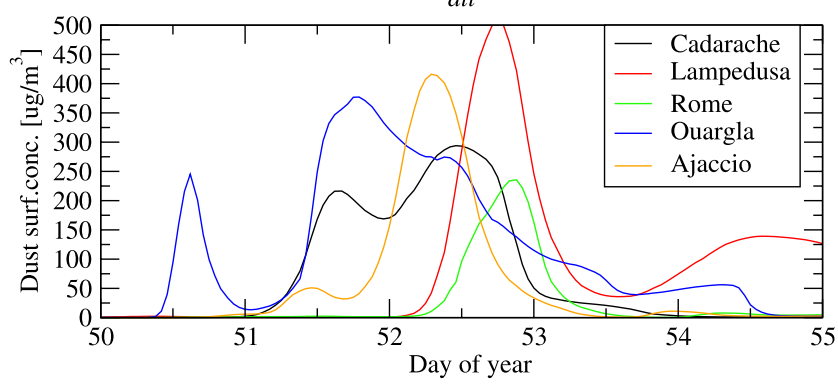

Figure 4. Dust surface concentrations $\left(\mu \mathrm{g} \mathrm{m}^{-3}\right)$ for several sites in southern France and Italy. Day 53 is 22 February 2004. 


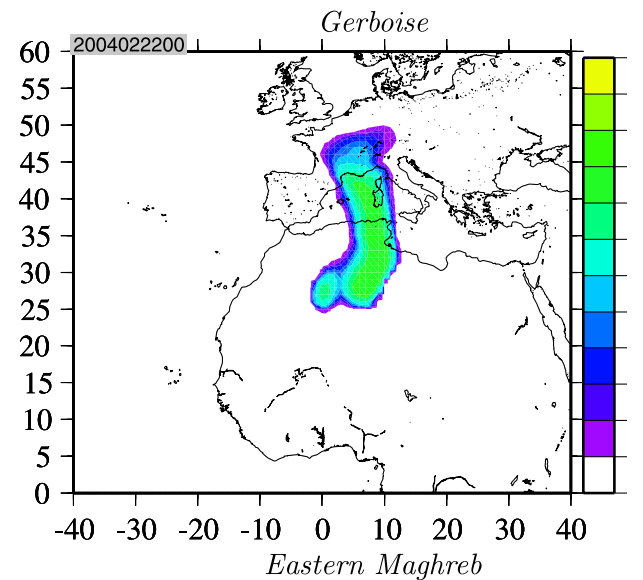

1000.0

200.0

50.0

10.0

4.0

2.0

1.0

0.7

0.5

0.3

0.2

0.1

0.0
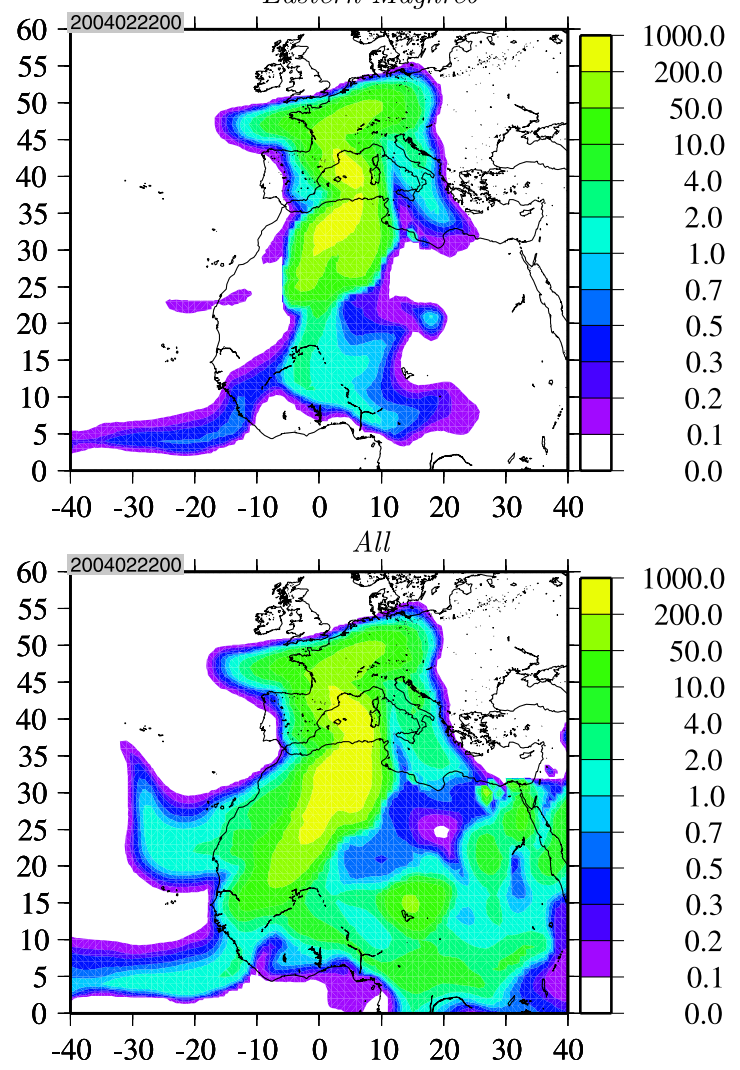

Figure 5. Surface concentrations for the 22 (0000 UTC) February 2004. (top) Dust emissions only in the "Gerboise" corresponding grid cell, (middle) dust emissions only in the "eastern Maghreb" grid cells, and (bottom) the complete dust emissions inventory.

contributions of the surface emission fluxes, the atmospheric burden (dust load over the whole domain), the dust surface concentrations and the dry deposition fluxes. If the percentages are between 0 and $100 \%$ for the "eastern Maghreb" configuration, the maxima never exceeds $1 \%$ for the "Gerboise" contribution.

[31] It is interesting to note that "eastern Maghreb" is a major contributor of the modeled dust two times during the period. The second time, for days 52 (21 February 2004) and 53 (22 February 2004), the surface emissions are close to $100 \%$. Because of dry deposition and emission magnitudes, possibly different from one place to another, the contribution to surface concentrations are less than $50 \%$. This is different for "Gerboise." Its contribution is $0.285 \%$ for the emissions fluxes, $0.275 \%$ for the atmospheric burden and $0.267 \%$ for the dry deposition. These close values show the model domain used covered the whole contribution: there is no matter leaving the domain on its boundaries (lateral and top). Thus the following analysis of the relative contribution of Gerboise could not be biased by boundaries effects. It also shows that the small area representing the Gerboise site is not a major contributor to the atmospheric dust emitted. But the most important values occurred for the studied event: for days 52 and 53 (21 and 22 February 2004, respectively), "Gerboise" represents $0.7 \%$ of the total emissions, dust load and surface concentrations as well as dry deposition fluxes. This shows that for this specific event, and over the whole domain, the relative contribution of "Gerboise" is four times higher than on average.

\subsection{Relative Contribution: Surface Concentrations}

[32] For selected target sites, a ratio of the surface dust concentrations between "Gerboise," "eastern Maghreb" and "all" are performed. The results are presented in Figure 7. In this case, the values are only taken at the mesh cell corresponding to the site location.

[33] For the "Gerboise"/" all" results, the first peak is the most important one and corresponds to the northern Africa
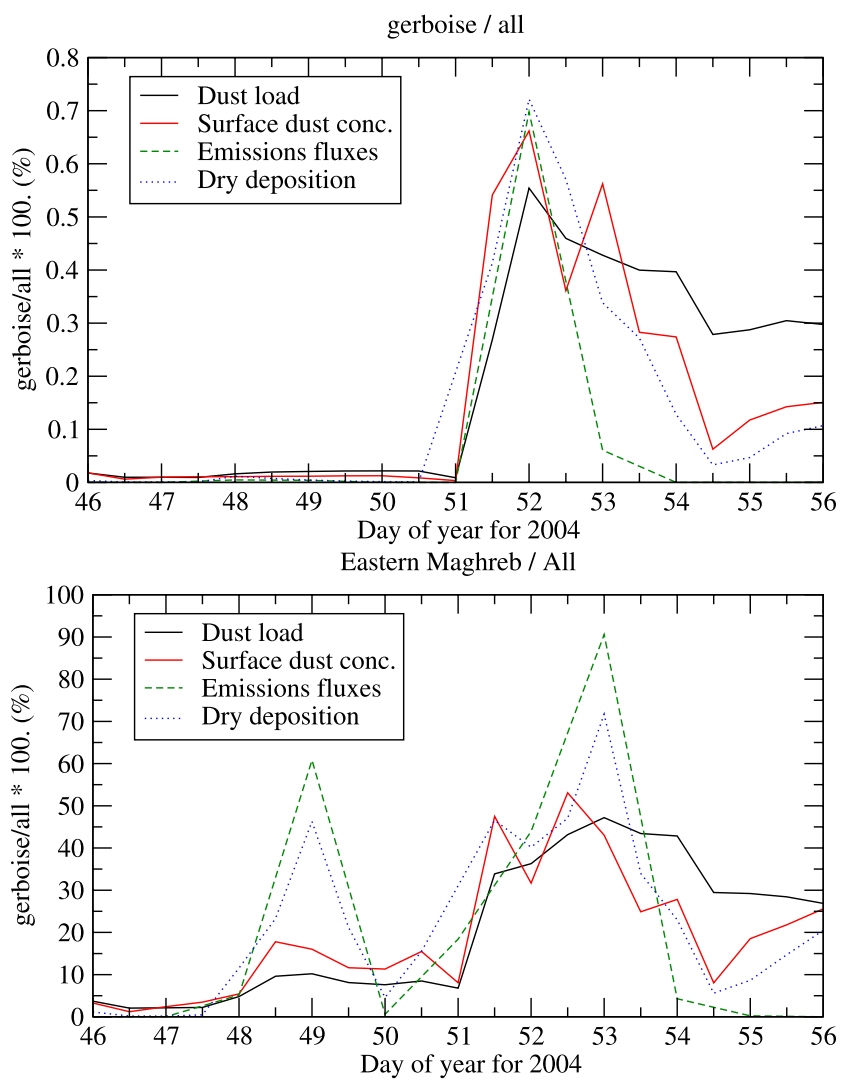

Figure 6. Ratio of cumulated dust emissions fluxes, dust concentrations (load and surface), and dry deposition fluxes over the whole domain for (top) the "Gerboise" and "all" and (bottom) the "eastern Maghreb" and "all" configurations, in $\%$. 
Gerboise / All
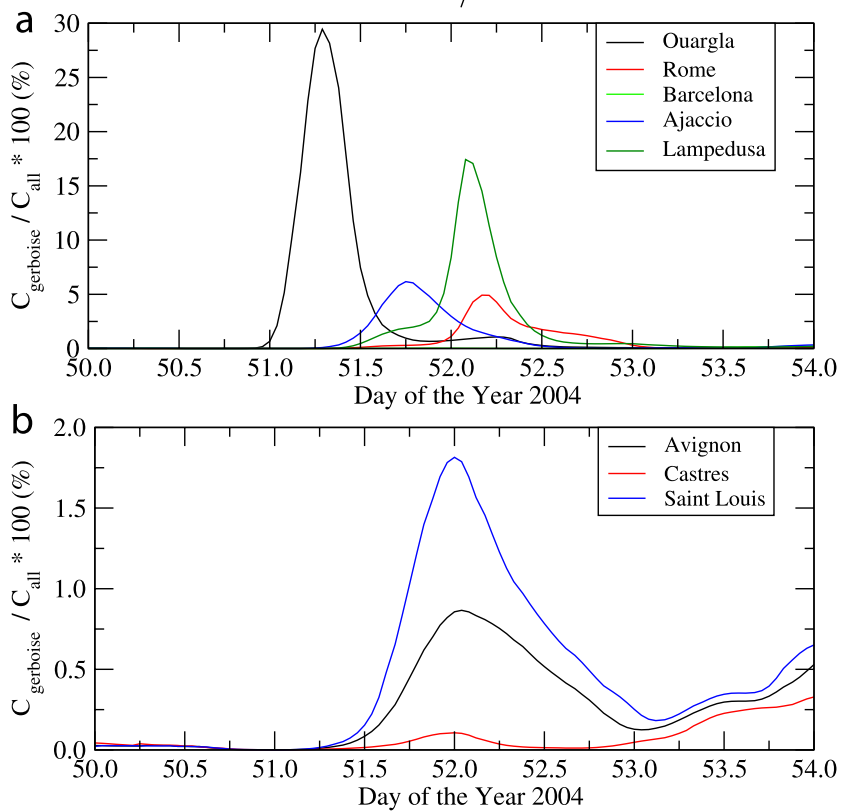

Eastern Maghreb / All
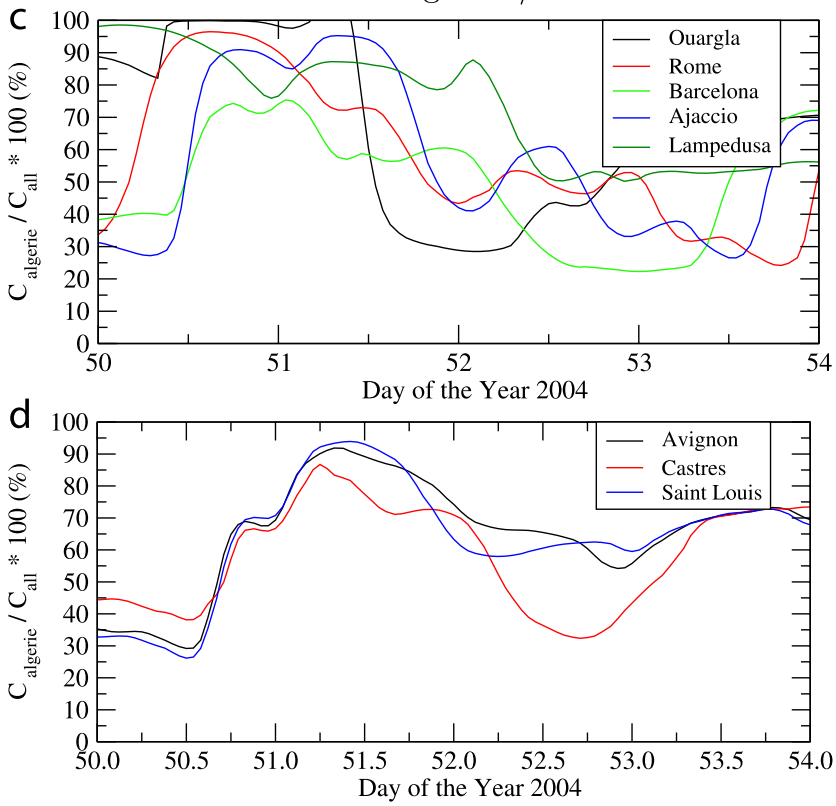

Figure 7. Time series of concentrations ratios between the different simulations: ( $\mathrm{a}$ and $\mathrm{b}$ ) the "Gerboise" and "all" and (c and d) the "eastern Maghreb" and "all" configurations. Figures $7 \mathrm{a}$ and $7 \mathrm{c}$ show sites in northern Africa, Spain, and Italy, and Figures $7 \mathrm{~b}$ and $7 \mathrm{~d}$ show sites in southern France where ${ }^{137} \mathrm{Cs}$ measurements are available. For each plot, results are presented as $c_{\text {gerboise }} / c_{\text {all }} \times 100(\%)$ and $c_{\text {algerie }} / c_{\text {all }} \times 100(\%)$.

site, Ouargla in Algeria. It corresponds to 20 February around 0800 UTC and shows that the relative contribution of the Gerboise site may reach $29.44 \%$. The other peaks are for the following days, 22 and 23 February, and correspond to the time for the plume to cross the Mediterranean Sea. The second important peak is in Corsica and is $6.16 \%$. Toward the east, the third peak is modeled in another island, Lampedusa and is estimated to be $17.42 \%$. For the sites in the south of France, where ${ }^{137} \mathrm{Cs}$ concentrations and masses were analyzed, the maxima of relative contributions are $\approx 1.8 \%$ for Saint Louis and $0.8 \%$ in Avignon. In these cases, the relative contribution of "Gerboise" is 9 and 4 four times higher than in average.

[34] This is in a lesser extent than for the "eastern Maghreb"/“all" results. The percentage are always between 40 and $100 \%$. For 22 February 2004, the mean contribution is $\approx 70 \%$ for the sites located in the south of France. But contrarily to the "Gerboise" configuration, the relative contribution of "eastern Maghreb" do not show a specific peak for the studied day.

[35] In order to have another view of "Gerboise" and "eastern Maghreb" impacts on the southern parts of France and Italy, maps of surface dust concentrations ratios, $c_{\text {Gerboise }} / c_{\text {all }}$ are displayed in Figure 8 (left) and

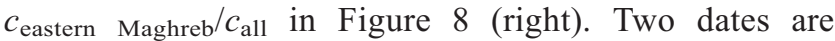
presented: 22 and 23 February 2004 at noon. The contribution of "Gerboise" is clear with a plume going from northern Africa to the south of France and Italy. The most important relative contributions are in the northern Italy with values around 20\%. For the "eastern Maghreb" contribution, the percentages mainly show that the more or less whole amount of dust particles recorded in Europe are coming from this area.

\subsection{Capability to Link the Source and All Remote Measurements}

[36] It is clear that, for the studied period, the relative contribution of the Gerboise site is higher than in average. In addition, this is remarkable to see that the "Gerboise" plume was transported just above the sites where high ${ }^{137} \mathrm{Cs}$ masses were recorded. Thus, we can made the hypothesis that a non negligible amount of the recorded ${ }^{137} \mathrm{Cs}$ originates from the "Gerboise" site. The main lack is missing local measurements of aerosols: the only measurements found in the literature are soil samples done by International Atomic Energy Agency (IAEA) [2005].

[37] A climatological value of ${ }^{137} \mathrm{Cs}$ around the Sahara (including the south of France) was found to be $34 \pm 1.9 \mathrm{~Bq} /$ $\mathrm{kg}$ [Igarashi et al., 2005]. In the same time, the mean activity value recorded during the episode is $38.7 \pm 3.4 \mathrm{~Bq} /$ $\mathrm{kg}$ during the whole day of 21 February. If we consider that the difference between the two values is significant, we can extrapolate the difference as the relative contribution of Gerboise: $4.7 \pm 10 \mathrm{~Bq} / \mathrm{kg}$. This represents $12 \%$ of the activity levels recorded in La Seyne sur Mer, knowing that only $0.8 \%$ of the modeled concentrations are from Gerboise: this means that in Gerboise, local activity levels $(\mathrm{Bq} / \mathrm{kg})$ are more or less ten times more intense than in the south of France, i.e., $\approx 400 \mathrm{~Bq} / \mathrm{kg}$. This latter value would correspond to an homogeneous concentrations in a model grid cell (in our case a squared degree grid cell). The IAEA report $[I A E A, 2005]$ presents soil measurements over an area of $2 \times 2 \mathrm{~km}$ around the Gerboise site, as presented in Figure 9: the horizontal gradient is stiff and concentrations in soil samples decrease with 2 order of magnitudes from the center of the experiment to a range of less than $1 \mathrm{~km}$. This means that the value of $400 \mathrm{~Bq} / \mathrm{kg}$ can be safely considered as a minimum in the vicinity of Gerboise sites. But without any additional measurements in the air of aerosolized particles (and not only in the soils), this is not 
Gerboise 22 Feb. 2004, 12:00 UTC
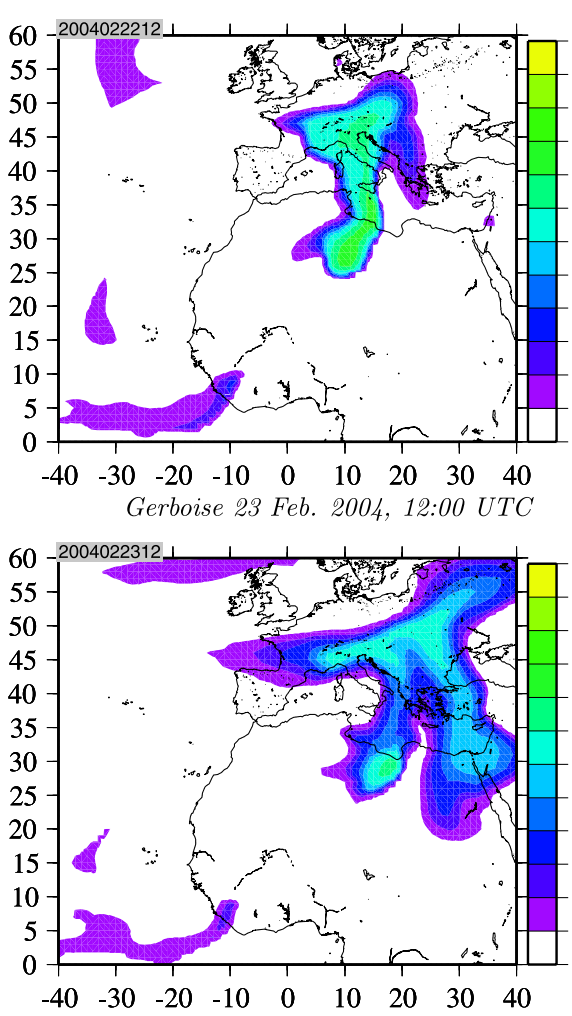

Eastern Maghreb 22 Feb. 2004, 12:00 UTC
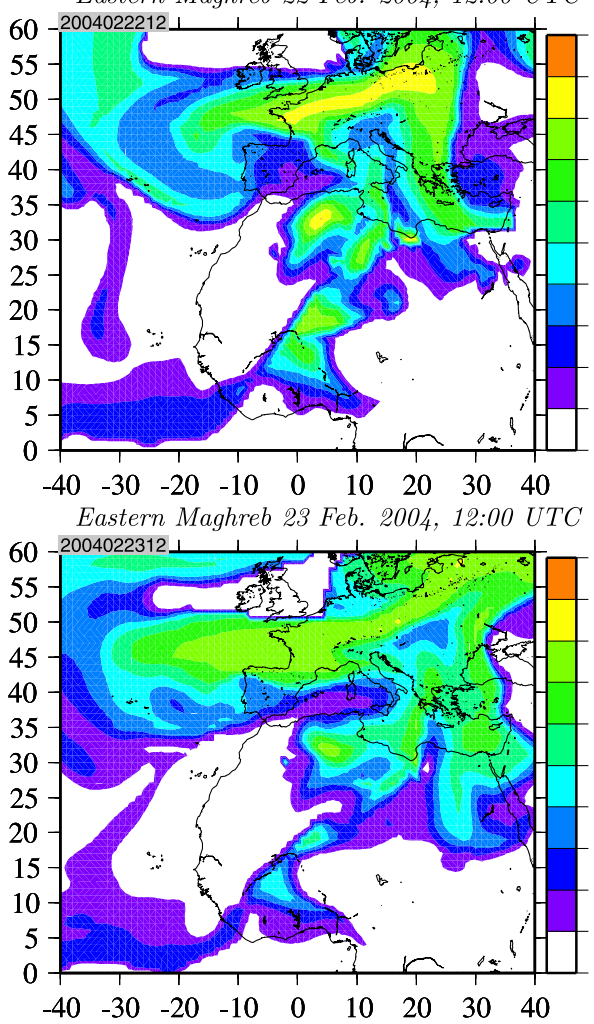

Figure 8. Maps of surface dust concentrations ratios of (left) $c_{\text {Gerboise }} / c_{\text {all }}$ and (right) $c_{\text {eastern Maghreb }} / c_{\text {all }}$ expressed in percentages.

really possible to conclude about the real value of activity levels in the vicinity of Gerboise during dust outbreaks.

[38] The next steps for this kind of study may be twofold: the need of additional data is clear and it would be recommended to measure dust concentrations in the atmospheric surface layer all around the Gerboise site and certainly during dust episodes. The second gap is the exact size distribution and mineralogy of these dust: after Vejsada et al. [2005] and Cook et al. [2007, and references therein], it is known that ${ }^{137} \mathrm{Cs}$ is mainly fixed on clay, the fraction of the smallest particles in the size distribution $(<2 \mu \mathrm{m})$. This may explain that soil samples have relatively low activity levels (a large amount of mass for a relative low amount of fine particles) when dust in the atmosphere may have a relatively highest activity level: the largest particles are deposited in the vicinity of their emissions and only the fine particles, clay with ${ }^{137} \mathrm{Cs}$, are transported far away.

\section{Conclusion}

[39] In this paper, the dust event of 21-23 February 2004 was studied. First using a chemistry transport model CHIMERE and a specific dust version CHIMERE-DUST, it was showed that this particulate matter event observed in the south of France was due to a major Saharan dust event. The model is close to the measurements done by air quality networks and enables us to explain huge concentrations documented during these days.

[40] In parallel, ${ }^{137} \mathrm{Cs}$ measurements were done during this period in the south of France by the OPERA network and showed unusual ${ }^{137} \mathrm{Cs}$ concentrations and deposited masses. The ratio of ${ }^{137} \mathrm{Cs} /{ }^{239+240} \mathrm{Pu}$ also showed that the samples are not originated from Chernobyl. The question is, Is the sudden increase of measured ${ }^{137} \mathrm{Cs}$ only due to a huge amount of dust (with an usual radionuclide content), import of highest contaminated air masses, or both?

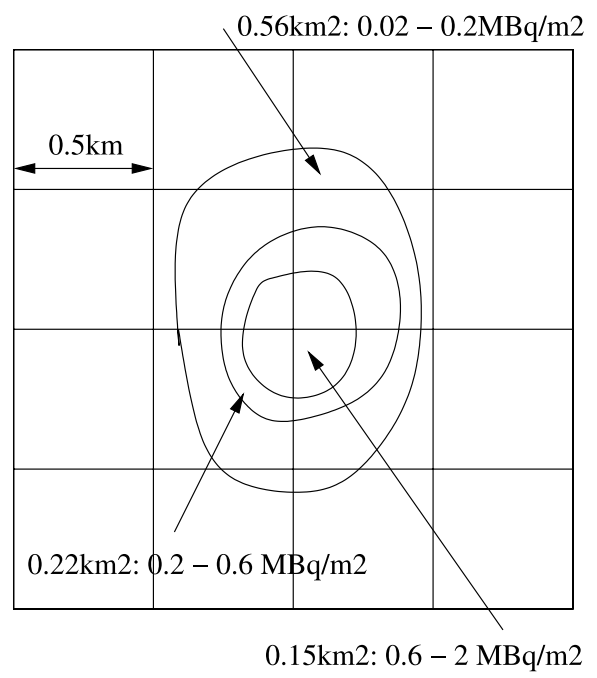

Figure 9. Surface isopleths of soil activity levels measurements as presented by IAEA [2005]. From the center of the curves (i.e., the nuclear experimental mast) and the last measurement point, the horizontal gradient ranges from 2 $\mathrm{MBq} / \mathrm{m}^{2}$ to $0.02 \mathrm{MBq} / \mathrm{m}^{2}$ over a distance of less than $1 \mathrm{~km}$. 
[41] Related to this region, the question may be focussed on the "Gerboise" site where former French nuclear tests in the 1960s happened. This constitutes an always open discussion about a potential contribution or not of this region on radionuclide activity levels.

[42] The first a priori conclusion would be no: the nuclear tests cannot be at the origin of these ${ }^{137} \mathrm{Cs}$ concentrations. Several studies showed that local soil activity levels at the Gerboise site are now negligible. In addition, the isotopic study gives a ratio typical of the global fallout from all the nuclear weapon tests that were performed in the atmosphere between 1945 and 1980; and not a typical signature that could be attributed to the four French nuclear atmospheric tests.

[43] In this paper, a dust transport model, CHIMEREDUST, was used in a scenario mode, to estimate a first quantification of the relative amount of the eastern Maghreb (a region encompassing Gerboise) and Gerboise itself on the surface dust concentrations observed in the south of Europe.

[44] Three model simulations were performed: one with the "complete" dust emissions inventory of CHIMEREDUST and two others with reduced emissions inventories: eastern Maghreb and Gerboise (a squared area of $1^{\circ} \times 1^{\circ}$ ). First, it was shown that the averaged contribution of Gerboise on the total amount of dust is $0.28 \%$. When looking more precisely day by day, it was shown that this relative contribution suddenly increase until $0.7 \%$ for the days of the episode. This is rather low compared to the whole contribution of the eastern Maghreb: 40 to 50\% of the dust modeled in the south of Europe.

[45] For specific sites in the south of France, the relative "Gerboise" ratio increases again and reached $1.8 \%$ in SaintLouis, a site near La Seyne sur Mer where ${ }^{137} \mathrm{Cs}$ mass was recorded 6 times higher than the usual averaged values.

[46] These remote percentages of concentrations were discussed in the same time than the local Gerboise soil measurements: considering the affinity of ${ }^{137} \mathrm{Cs}$ on clay, the important horizontal gradient in the vicinity of Gerboise and the capability of dust to be transported toward remote sites, it seems clear that Gerboise concentrations may be important. But it was also highlighted that actual data and knowledge are not sufficient to propose more acute conclusions. Recommendations were done in order to more precisely quantify the real activity levels of aerosols emitted in the Sahara and transported in the south of France.

[47] Acknowledgment. Philippe Hubert (INERIS) is acknowledged for fruitful scientific discussions.

\section{References}

Alfaro, S. C., and L. Gomes (2001), Modeling mineral aerosol production by wind erosion: Emission intensities and aerosol size distribution in source areas, J. Geophys. Res., 106, 18,075-18,084.

Aoyama, M., K. Hirose, and Y. Igarashi (2006), Re-construction and updating our understanding on the global weapons tests ${ }^{137} \mathrm{Cs}$ fallout, J. Environ. Monit., 8, 431-438.

Baggoura, B., A. Nourredine, and M. Benkrid (1998), Level of natural and artificial radioactivity in Algeria, Appl. Radiat. Isotopes, 49, 867-873.

Bessagnet, B., A. Hodzic, R. Vautard, M. Beekmann, S. Cheinet, C. Honoré, C. Liousse, and L. Rouil (2004), Aerosol modeling with CHIMERE: Preliminary evaluation at the continental scale, Atmos. Environ., 38, $2803-$ 2817.

Bouisset, P., E. Barker, O. Masson, R. Gurriaran, X. Cagnat, D. Mekhlouche, S. Aubry, M. Hadjaj, and L. Saey (2004), Concentration de ${ }^{137} \mathrm{Cs}$ et de ${ }^{7} \mathrm{Be}$ dans les aérosols en France de 1959 à 2002, Radioprotection, 39, 367-381.
Brandt, J., J. H. Christensen, and L. M. Frohn (2002), Modelling transport and deposition of caesium and iodine from the Chernobyl accident using the DREAM model, Atmos. Chem. Phys., 2, 397-417.

Campbell, B., R. Loughran, and G. Elliott (2008), Caesium-137 as an indicator of geomorphic processes in a drainage basin system, Aust. Geogr. Stud., 20, 49-64.

Colette, A., L. Menut, M. Haeffelin, and Y. Morille (2008), Impact of the transport of aerosols from the free troposphere towards the boundary layer on the air quality in the Paris area, Atmos. Environ., 42(2), 390402, doi:10.1016/j.atmosenv.2007.09.044.

Cook, L., R. Inouye, T. McGonigle, and G. White (2007), The distribution of stable cesium in soils and plants of the eastern Snake River plain in southern Idaho, J. Arid Environ., 69(1), 40-64, doi:10.1016/j.jaridenv. 2006.08.014.

Danesi, P., J. Moreno, M. Makarewicz, and D. Louvat (2008), Residual radionuclide concentrations and estimated radiation doses at the former French nuclear weapons test sites in Algeria, Appl. Radiat. Isotopes, 66, $1671-1674$

De Cort, M. (1998), Atlas of Caesium Deposition on Europe After the Chernobyl Accident, Off. for Off. Publ. of Eur. Commun., Luxembourg. Dudhia, J. (1993), A nonhydrostatic version of the Penn State/NCAR mesoscale model: Validation tests and simulation of an atlantic cyclone and cold front, Mon. Weather Rev., 121, 1493-1513.

Escudero, M., X. Querol, A. Avila, and E. Cuevas (2007), Origin of the exceedances of the European daily PM limit value in regional background areas of Spain, Atmos. Environ., 41, 730-744, doi:10.1016/j. atmosenv.2006.09.014

Fukuyama, T., and H. Fujiwara (2008), Contribution of Asian dust to atmospheric deposition of radioactive cesium ( $\left.{ }^{137} \mathrm{cs}\right)$, Sci. Total Environ., 405, $389-395$.

Honoré, C., et al. (2008), Predictability of European air quality: Assessment of 3 years of operational forecasts and analyses by the PREV'AIR system, J. Geophys. Res., 113, D04301, doi:10.1029/2007JD008761.

Igarashi, Y., M. Aoyama, K. Hirose, T. Miyao, and S. Yabuki (2001), Is it possible to use ${ }^{90} \mathrm{SR}$ and ${ }^{137} \mathrm{Cs}$ as tracers for the aeolian dust transport?, Water Air Soil Pollut., 4, 349-354.

Igarashi, Y., M. Aoyama, K. Hirose, P. Povinec, and S. Yabuki (2005), What anthropogenic radionuclides ${ }^{90} \mathrm{Sr}$ and $\left.{ }^{137} \mathrm{Cs}\right)$ in atmospheric deposition surface soils and aeolian dusts suggest for dust transport over Japan?, Water Air Soil Pollut., 5, 51-69.

International Atomic Energy Agency (IAEA) (2005), Radiological conditions at the former French nuclear test sites in Algeria: Preliminary assessment and recommendations, Radiol. Assess. Rep. Ser., STI/PUB 1215, Vienna.

Kalnay, E., et al. (1996), The NCEP/NCAR 40-year reanalysis project, Bull. Am. Meteorol. Soc., 77, 437-471.

Karlsson, L., F. Hernandez, S. Rodriguez, M. Lopez-Perez, J. HernandezArmas, S. Alonso-Perez, and E. Cuevas (2008), Using ${ }^{137} \mathrm{Cs}$ and ${ }^{40} \mathrm{~K}$ to identify natural Saharan dust contributions to PM10 concentrations and air quality impairment in the Canary Islands, Atmos. Environ., 42, 7034 7042, doi:10.1016/j.atmosenv.2008.06.016.

Kulan, A. (2006), Seasonal ${ }^{7} \mathrm{Be}$ and ${ }^{137} \mathrm{Cs}$ activities in surface air before and after the chernobyl event, J. Environ. Radioact., 90, 140-150, doi:10.1016/j.jenvrad.2006.06.010.

Loosmore, G., and R. Cederwall (2004), Precipitation scavenging of atmospheric aerosols for emergency response applications: Testing an updated model with new real-time data, Atmos. Environ., 38, 993-1003.

Lyamani, H., F. Olmo, and L. Alados-Arboledas (2005), Saharan dust outbreak over southeastern Spain as detected by sun photometer, Atmos. Environ., 39, 7276-7284, doi:10.1016/j.atmosenv.2005.09.011.

Marticorena, B., and G. Bergametti (1995), Modeling the atmospheric dust cycle: 1 . Design of a soil derived dust production scheme, J. Geophys. Res., 100, 16,415-16,430.

Masson, O., and G. Cautenet (2005), Radioecological impact of saharan dust fallout: Study of a major event over south part of France in February 2004, paper presented at First ACCENT Symposium: The Changing Chemical Climate of the Atmosphere, Atmos. Composition Change: The Eur. Network of Excellence, Urbino, Italy.

Menut, L. (2003), Adjoint modelling for atmospheric pollution processes sensitivity at regional scale during the ESQUIF IOP2, J. Geophys. Res., 108(D17), 8562, doi:10.1029/2002JD002549.

Menut, L. (2008), Sensitivity of hourly Saharan dust emissions to NCEP and ECMWF modeled wind speed, J. Geophys. Res., 113, D16201, doi:10.1029/2007JD009522.

Menut, L., C. Schmechtig, and B. Marticorena (2005), Sensitivity of the sandblasting fluxes calculations to the soil size distribution accuracy, J. Atmos. Oceanic Technol., 22, 1875-1884.

Menut, L., G. Foret, and G. Bergametti (2007), Sensitivity of mineral dust concentrations to the model size distribution accuracy, J. Geophys. Res., 112, D10210, doi:10.1029/2006JD007766. 
Papastefanou, C., M. Manolopoulou, S. Stoulos, A. Ioannidou, and E. Gerasopoulos (2001), Coloured rain dust from Sahara desert is still radioactive, J. Environ. Radioact., 55, 109-112.

Pollanen, R., I. Valkama, and H. Toivonen (1997), Transport of radioactive particles from the Chernobyl accident, Atmos. Environ., 31, 3575-3590.

Putaud, J.-P. (2004), A European aerosol phenomenology-2: Chemical characteristics of particulate matter at kerbside, urban, rural and background sites in Europe, Atmos. Environ., 38, 2579-2595.

Troen, I., and L. Mahrt (1986), A simple model of the atmospheric boundary layer: Sensitivity to surface evaporation, Boundary Layer Meteorol., $37,129-148$

United Nations Scientific Committee on the Effects of Atomic Radiation (1982), Ionizing radiation: Sources and biological effects, technical repport, Vienna.

Vanderstraeten, P., Y. Lenelle, A. Meurrens, D. Carati, L. Brenig, A. Delcloo, Z. Offer, and E. Zaady (2008), Dust storm originate from Sahara covering western Europe: A case study, Atmos. Environ., 42, 5489-5493, doi:10.1016/j.atmosenv.2008.02.063.

Van Leer, B. (1979), Towards the ultimate conservative difference scheme.V. A second order sequel to Godunov's method, J. Comput. Phys., 32, 101-136.

Vautard, R., S. Szopa, M. Beekmann, L. Menut, D. A. Hauglustaine, L. Rouil, and M. Roemer (2006), Are decadal anthropogenic emission reductions in Europe consistent with surface ozone observations?, Geophys. Res. Lett., 33, L13810, doi:10.1029/2006GL026080.

Vejsada, J., E. Jelinek, Z. Randa, D. Hradil, and R. Prikryl (2005), Sorption of cesium on smectite-rich clays from the Bohemian Massif (Czech Republic) and their mixtures with sand, Appl. Radiat. Isotopes, 62(1), 91-96, doi:10.1016/j.apradiso.2004.05.075.

Venkatram, A., and J. Pleim (1999), The electrical analogy does not apply to modeling dry deposition of particles, Atmos. Environ., 33, 3075-3076. Wagenpfeil, F., H. Paretzke, J. Peres, and J. Tschiersch (1999), Resuspension of coarse particles in the region of Chernobyl, Atmos. Environ., 33, $3313-3323$.

B. Bessagnet, Institut National de l'Environnement Industriel et des Risques, Parc technologique ALATA, F-60550 Verneuil en Halatte, France.

O. Masson, Service d'Etudes et de Surveillance de la Radioactivité dans l'Environnement, Direction de l'Environnement et de l'Intervention, Institut de Radioprotection et de Sûreté Nucléaire, BP3, F-13115 Saint Paul lez Durance, France.

L. Menut, Laboratoire de Météorologie Dynamique, Institut Pierre-Simon Laplace, Ecole Polytechnique, F-91128 Palaiseau, France. (menut@lmd. polytechnique.fr) 